\title{
INFLUENCE OF FIBER REINFORCEMENT ON CONCRETE SHRINKAGE FOR RIGID ROAD AND AIRFIELD PAVEMENT REPAIR
}

\author{
${ }^{1}$ Kroviakov S.O., Doctor of Engineering, Assistant Professor, \\ skrovyakov@ukr.net, ORCID: 0000-0002-0800-0123 \\ ${ }^{1}$ Kryzhanovskyi V.O., Engineer, \\ vitolloscience@gmail.com, ORCID: 0000-0003-1332-1922 \\ ${ }^{1}$ Odessa State Academy of Civil Engineering and Architecture \\ 4, Didrichson street, Odessa, 65029, Ukraine
}

\begin{abstract}
The influence of fiber reinforcement with steel anchor fiber on the shrinkage of modified concrete for rigid airfield pavements repair has been determined. A 2-factor experiment was carried out, in which the following composition factors were varied: the amount of hardening accelerator Sika Rapid 3 from 0 to $2.4 \%$ of the cement content $\left(0-9.6 \mathrm{~kg} / \mathrm{m}^{3}\right)$; the amount of steel anchor fiber with $1 \mathrm{~mm}$ diameter and $50 \mathrm{~mm}$ length, from 0 to $100 \mathrm{~kg} / \mathrm{m}^{3}$. For the concrete batching were used: Portland cement CEM II / AS 42.5 in the amount of $400 \mathrm{~kg} / \mathrm{m}^{3}$, granite crushed stone 5$20 \mathrm{~mm}$, quartz sand, plasticizer admixture BASF MasterGlenium SKY 608 in the amount of 1.2\% by cement content.
\end{abstract}

The workability of the mixtures was $\mathrm{S} 2(6-8 \mathrm{~cm})$; W/C ratio depended on the concrete composition. Due to the use of superplasticizers, the W/C of all investigated mixtures was in the range of $0.309-0.343$.

The shrinkage of the prism specimens was recorded after 3 hours, 6 hours, 1, 2, 3 and 7 days of being in air-dry conditions. The shrinkage process does not end after 7 days of concrete hardening, however, the general nature of the influence of variable factors on its value remains. It has been established that fiber-reinforced concretes, with a fiber amount of $50 \mathrm{~kg} / \mathrm{m}^{3}$ and with a fiber amount of $100 \mathrm{~kg} / \mathrm{m}^{3}$, have $10-15 \%$ less shrinkage compared to unreinforced concretes. Compositions with a fiber amount of $50 \mathrm{~kg} / \mathrm{m}^{3}$ and $100 \mathrm{~kg} / \mathrm{m}^{3}$ have practically the same shrinkage, which is explained by an increase in W/C ratio with an increase in the amount of fiber reinforcement. The amount of hardening accelerator has a less noticeable effect on the amount of concrete shrinkage. By adding Sika Rapid 3, concrete shrinkage at the age of 7 days is reduced by 2-9\%. This effect can be explained by the fact that internal stresses arising in the process of structure formation and moisture loss in concrete are contained in a more durable cement-sand matrix. The concrete shrinkage without fiber and accelerator was also measured up to the age of 98 days. It was found that the limiting shrinkage for such concrete is $\varepsilon \approx 2.5 \times 10^{-4}$.

The analysis of the drawn experimental-statistical model showed that with the amount of metal fiber from 60 to $90 \mathrm{~kg} / \mathrm{m}^{3}$ and the amount of the hardening accelerator from 0.9 to $2.4 \%$, the shrinkage of the investigated concretes is minimal $\left(\varepsilon_{7}=1.3 \times 10^{-4}\right)$.

Thus, the use of fiber reinforcement with anchor steel fiber and a hardening accelerator can significantly reduce the concrete shrinkage for the rigid airfield pavements repair is important for this material.

Keywords: rigid pavements, airport paving, repair, shrinkage, metal fiber, hardening accelerator.

Introduction. In the USA, China, the countries of the European Union and other developed countries, rigid road and airfield pavements are widely used. In recent years, cement concrete has been increasingly used in Ukraine in the construction and reconstruction of highways, airport runways and taxiways. Today, the country operates cement concrete highways and runways, mainly of reinforced concrete slabs, built in the 20th century. Task of creating effective concretes for the cement-concrete pavements repair is becoming more urgent. 
For repair concrete, shrinkage during hardening is an important characteristic, since shrinkage deformations can cause cracking and/or disrupt their adhesion to the road or airfield surface that is being repaired. A decrease in shrinkage deformations can be achieved through the use of various methods, in particular, dispersed reinforcement with steel fibers. In addition, fiber reinforcement makes it possible to increase a number of physical and mechanical properties, which are important for road and airfield concrete pavements. Thus, the task of reducing concrete shrinkage for the rigid pavements repair through the use of a rational amount of steel fiber is urgent.

Analysis of recent research and publications. The technology of rigid pavement full-depth rapid repair is increasingly used in world practice to maximize highway maintenance functions while minimizing disruptions to the operation of transport systems [1]. At the same time, the repair material must ensure the design strength, meet the operating conditions, ensure proper adhesion to the existing concrete and allow faster opening of traffic [2].

The composition of concrete mixtures used for full-depth rapid repair often includes superplasticizers, hardening accelerators [3], and dispersed reinforcement (fiber) of various types [4]. In [5], it is recommended to use steel or polypropylene fiber for repair concrete, which, in particular, helps to reduce the number of cracks during hardening. Fiber allows increasing the strength, abrasion resistance and impact resistance of concretes for the rigid pavement repair, while the shrinkage of the material due to the introduction of fibers is reduced [6]. In [7], it is recommended to use fiber-concrete mixtures with the amount of steel fiber from 25 to $50 \mathrm{~kg} / \mathrm{m}^{3}$ as repair material, and it is noted that the most effective use of such repair materials on highways with a rigid pavement. In [8], it is recommended to introduce steel fiber in combination with an air-entraining admixture and a plasticizer. It is shown in [9] that using rational amount of a hardening accelerator, steel anchor fiber and superplasticizer allows achieving modified fiber concretes that are characterized by high compressive strength and flexural strength at an early age and at the age of 28 days. That is, in general, modified fiber-reinforced concretes are effective materials for rigid highway and airfield pavements repair, however, the task of reducing their shrinkage cannot be considered solved, especially taking into account the cements available on the Ukrainian market.

Research objective is to determine the effect of the anchor steel fiber amount and a hardening accelerator on the shrinkage deformations of concrete modified with a polycarboxylate superplasticizer for the rigid airfield pavements repair.

Materials and methods. For the manufacture of concrete used: Portland cement ПЦ II/А-Ш500 (CEM II/AS 42.5) produced by CJSC Dyckerhoff Cement Ukraine (cement content - 400 $\left.\mathrm{kg} / \mathrm{m}^{3}\right)$, granite crushed stone $(5-20 \mathrm{~mm})$, quartz sand. BASF MasterGlenium SKY 608 superplasticizer based on polycarboxylate ethers was used as a plasticizing admixture. The dosage of the admixture was $1,2 \%$ of the cement content $\left(4,8 \mathrm{~kg} / \mathrm{m}^{3}\right)$, which is a rational amount of this modifier for the studied concretes [10].

According to the optimal symmetric 9-point plan, a 2-factor experiment was carried out [11, 12], in which the following factors of concrete composition were varied [9]:

$\mathrm{X}_{1}$ - the amount of the hardening accelerator admixture Sika Rapid 3, from 0 to 2,4\% of the cement content (from 0 to $9,6 \mathrm{~kg} / \mathrm{m}^{3}$ );

$\mathrm{X}_{2}$-amount of steel anchor fiber with a diameter of $1 \mathrm{~mm}$ and a length of $50 \mathrm{~mm}$ (produced by PJSC PA "Stalkanat-Silur"), from 0 to $100 \mathrm{~kg} / \mathrm{m}^{3}$.

Concrete mixture was adjusted depending on the amount of fiber reinforcement and modifiers. The plan of the experiment and the concrete and fiber-concrete compositions investigated at 9 experimental points are shown in Table 1.

The shrinkage of concrete during hardening in air-dry conditions was determined as follows. Concrete prisms $10 \times 10 \times 40 \mathrm{~cm}$ for the first day after formation were stored in molds in a humidity chamber. After that, the prisms were stripped and they were placed in air-dry conditions (moisture $60 \pm 5 \%$, temperature $20 \pm 2{ }^{\circ} \mathrm{C}$ according to DSTU B V.2.7-216:2009). This made it possible to create conditions for the hardening of concrete, which are close to the conditions for hardening of repair concrete on highways and at airports. 
Table 1 - Experiment plan and compositions of the investigated concretes and fiber-reinforced concretes

\begin{tabular}{|c|c|c|c|c|c|c|c|c|c|}
\hline \multirow[b]{2}{*}{ 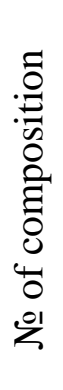 } & \multirow[b]{2}{*}{ 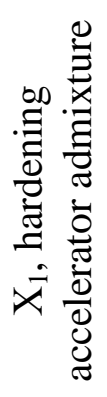 } & \multirow[b]{2}{*}{ 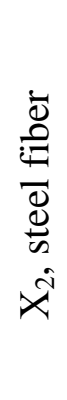 } & \multicolumn{7}{|c|}{ Concrete composition } \\
\hline & & & 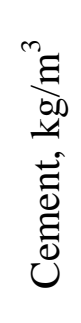 & 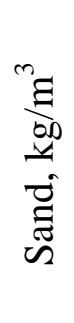 & 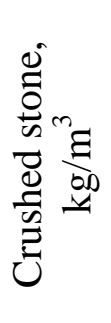 & 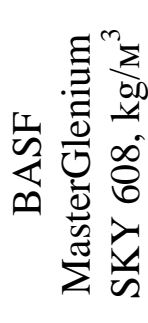 & 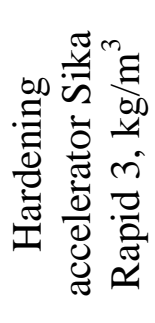 & 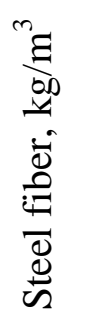 & 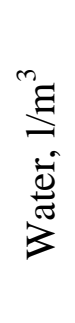 \\
\hline 1 & -1 & -1 & \multirow{9}{*}{400} & 830 & \multirow{3}{*}{1190} & \multirow{9}{*}{4,8} & 0 & \multirow{3}{*}{0} & 127 \\
\hline 2 & 0 & -1 & & 828 & & & 4,8 & & 126 \\
\hline 3 & +1 & -1 & & 825 & & & 9,6 & & 123 \\
\hline 4 & -1 & 0 & & 788 & \multirow{3}{*}{1180} & & 0 & \multirow{3}{*}{50} & 133 \\
\hline 5 & 0 & 0 & & 786 & & & 4,8 & & 131 \\
\hline 6 & +1 & 0 & & 782 & & & 9,6 & & 130 \\
\hline 7 & -1 & +1 & & 752 & \multirow{3}{*}{1170} & & 0 & \multirow{3}{*}{100} & 138 \\
\hline 8 & 0 & +1 & & 750 & & & 4,8 & & 135 \\
\hline 9 & +1 & +1 & & 745 & & & 9,6 & & 132 \\
\hline
\end{tabular}

Research results. The workability of all investigated mixtures was $6-8 \mathrm{~cm}$, respectively, their $\mathrm{W} / \mathrm{C}$ depended on the composition. It is known that $\mathrm{W} / \mathrm{C}$ is an important structural indicator for minimizing concrete shrinkage. It was found that the amount of the hardening accelerator insignificantly affects the W/C of mixtures of equal workability, and the introduction of fiber requires an insignificant increase in the W/C. Due to the use of MasterGlenium SKY 608 superplasticizer, the W/C of all studied mixtures was in the range of $0,309 . .0,343$, which allows ensuring high physical, mechanical and durability properties of concrete with satisfactory shrinkage values.

At the previous stages of the study, it was found that the amount of the hardening accelerator most significantly affects the early compressive strength of fiber-reinforced concrete [9]. Fiber also has a positive effect on early strength. Using the maximum amount of hardening accelerator, concrete has a strength of at least $55 \mathrm{MPa}$ after 2 days of hardening. Fibrous concretes with $50 \mathrm{~kg} / \mathrm{m}^{3}$ of fiber amount and more have the same strength even with $1,4 \%$ of hardening accelerator. The value of flexural strength at the age of 2 days is most influenced by the amount of steel anchor fiber. This effect is nonlinear and with an increase in the dose of fibers to $60 \mathrm{~kg} / \mathrm{m}^{3}$, the early flexural concrete strength increases more than $2 \mathrm{MPa}$. The $\mathrm{f}_{\text {ctt.2 }}$ reaches the highest values at a fiber dosage in the range of $85 . .90 \mathrm{~kg} / \mathrm{m}^{3}$, a further increase in the fibers amount already negatively effects on the early flexural strength. Due to the introduction of the hardening accelerator, early flexural strength of fiber-reinforced concrete increases by up to $0,6 \mathrm{MPa}$. With the amount of the hardening accelerator in the composition from $1,2 \%$ and with a steel fiber dosage of $60 \mathrm{~kg} / \mathrm{m}^{3}$ and higher, the early flexural strength of fiberreinforced concrete is not less than $8,5 \mathrm{MPa}$, which allows starting the operation of the pavement.

At 28 days age, fiber-reinforced concretes with a hardening accelerator have 10-12\% less compressive strength and flexural strength than concretes without Sika Rapid 3 admixture. However, the positive effect of dispersed reinforcement on strength becomes more noticeable than at the 2 days age. Using fiber in the amount of $70 . .90 \mathrm{~kg} / \mathrm{m}^{3}$, the concrete compressive strength increases by $9 . .10$ $\mathrm{MPa}$ and ranges from 80 to $90 \mathrm{MPa}$. The flexural strength due to dispersed reinforcement increases more than 2 times: from 7..8,5 $\mathrm{MPa}$ to $15,5 . .17,5 \mathrm{MPa}$. Such efficiency of the fiber at an older age is explained by the fact that the quality of the fibers work is largely due to their adhesion to the cement-sand matrix [13]. 
The shrinkage of the prism specimens was recorded after 3 hours, 6 hours, 1, 2, 3 and 7 days of being in air-dry conditions. The data of the concrete shrinkage of various compositions (averaged over the results of determining the shrinkage of 3 samples at each point of the plan) are given in Table 2.

Table 2 - Shrinkage of concrete and fiber-reinforced concrete during hardening in air-dry conditions

\begin{tabular}{|c|c|c|c|c|c|c|c|c|}
\hline \multirow{2}{*}{ 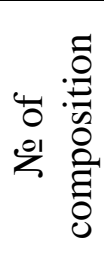 } & \multirow[b]{2}{*}{ 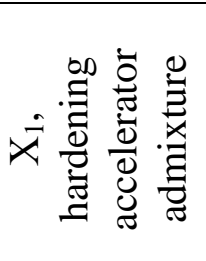 } & \multirow{2}{*}{$\begin{array}{l}\dot{\bar{\delta}} \\
\dot{0} \\
\bar{d} \\
\dot{\Phi} \\
\dot{\Delta} \\
\dot{x}\end{array}$} & \multicolumn{6}{|c|}{ Shrinkage $\varepsilon \times 10^{-4}$} \\
\hline & & & $\frac{n}{\Xi}$ & $\frac{n}{\Xi}$ & 吾 & $\underset{\sim}{\stackrel{\infty}{\delta}}$ & 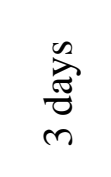 & $\underset{r}{\stackrel{\infty}{\delta}}$ \\
\hline 1 & -1 & -1 & 0,609 & 0,865 & 1,218 & 1,376 & 1,445 & 1,604 \\
\hline 2 & 0 & -1 & 0,653 & 0,890 & 1,221 & 1,342 & 1,383 & 1,507 \\
\hline 3 & +1 & -1 & 0,725 & 0,942 & 1,210 & 1,312 & 1,365 & 1,465 \\
\hline 4 & -1 & 0 & 0,565 & 0,748 & 1,070 & 1,211 & 1,275 & 1,353 \\
\hline 5 & 0 & 0 & 0,564 & 0,718 & 1,035 & 1,163 & 1,225 & 1,325 \\
\hline 6 & +1 & 0 & 0,660 & 0,820 & 1,082 & 1,203 & 1,214 & 1,337 \\
\hline 7 & -1 & +1 & 0,505 & 0,733 & 1,035 & 1,179 & 1,235 & 1,340 \\
\hline 8 & 0 & +1 & 0,528 & 0,750 & 1,031 & 1,153 & 1,212 & 1,304 \\
\hline 9 & +1 & +1 & 0,668 & 0,827 & 1,075 & 1,195 & 1,215 & 1,311 \\
\hline
\end{tabular}

According to the data given in Table 2, in Fig. 1 graphs showing the effect of the fiber amount on the concrete shrinkage with different amounts of Sika Rapid 3 in the composition.

Analysis of the graphs shows that the shrinkage process does not end after 7 days of concrete hardening, however, the general nature of the influence of variable composition factors on its value is quite pronounced. Regardless of the hardening accelerator amount, dispersion-reinforced concretes with fiber amount of $50 \mathrm{~kg} / \mathrm{m}^{3}$ and fiber amount of $100 \mathrm{~kg} / \mathrm{m}^{3}$ have a significantly lower shrinkage compared to unreinforced concretes. This is explained by the ability of the fiber framework to restrain the structural blocks of the composite from displacement due to moisture loss in the process of structure formation $[13,14]$. The fact that compositions with a fiber amount of $50 \mathrm{~kg} / \mathrm{m}^{3}$ and $100 \mathrm{~kg} / \mathrm{m}^{3}$ are characterized by almost the same shrinkage can be explained by the fact that with an increase in the amount of dispersed reinforcement, the W/C mixture increases. Positive influence of the spatial fiber mesh is leveled by the influence of an increased amount of water in the concrete mixture.

The amount of the hardening accelerator also effects on the shrinkage value of the investigated concretes, but less significantly. Due to the introduction of the Sika Rapid 3 maximum amount, the concrete shrinkage at the 7 days age is reduced by $3.9 \%$, with the introduction of $1,2 \%$ of this modifier - by $2 . .7 \%$. The decrease in shrinkage due to the use of the hardening accelerator is explained by the fact that internal stresses in the composite material, arising in the process of structure formation and moisture loss, are contained in a cement-sand matrix that is more durable in the early stages of hardening.

To determine the ultimate concrete shrinkage of composition No. 1 (without fiber and accelerator), the shrinkage of samples at the age of $14,28,42,56,70,84$ and 98 days was also measured. The shrinkage values at certain times were, respectively, 1,604, 1,827, 2,151, 2,327, 2,435, 2,494 and 2,501 $\times 10-4$. That is, after 84 days of hardening, shrinkage stabilized and the shrinkage value at the age of 98 days did not actually differ from the values at the 84 days age. Thus, the ultimate concrete shrinkage without dispersed reinforcement and accelerator was $\varepsilon \approx 2,5 \times 10^{-4}$ (or $0,25 \mathrm{~mm} / \mathrm{m}$ ), which is a satisfactory value. That is, the use of dispersed reinforcement with anchor steel fiber and 
hardening accelerator makes it possible to reduce the concrete shrinkage, which is important for the repair material of rigid road and airfield pavements.
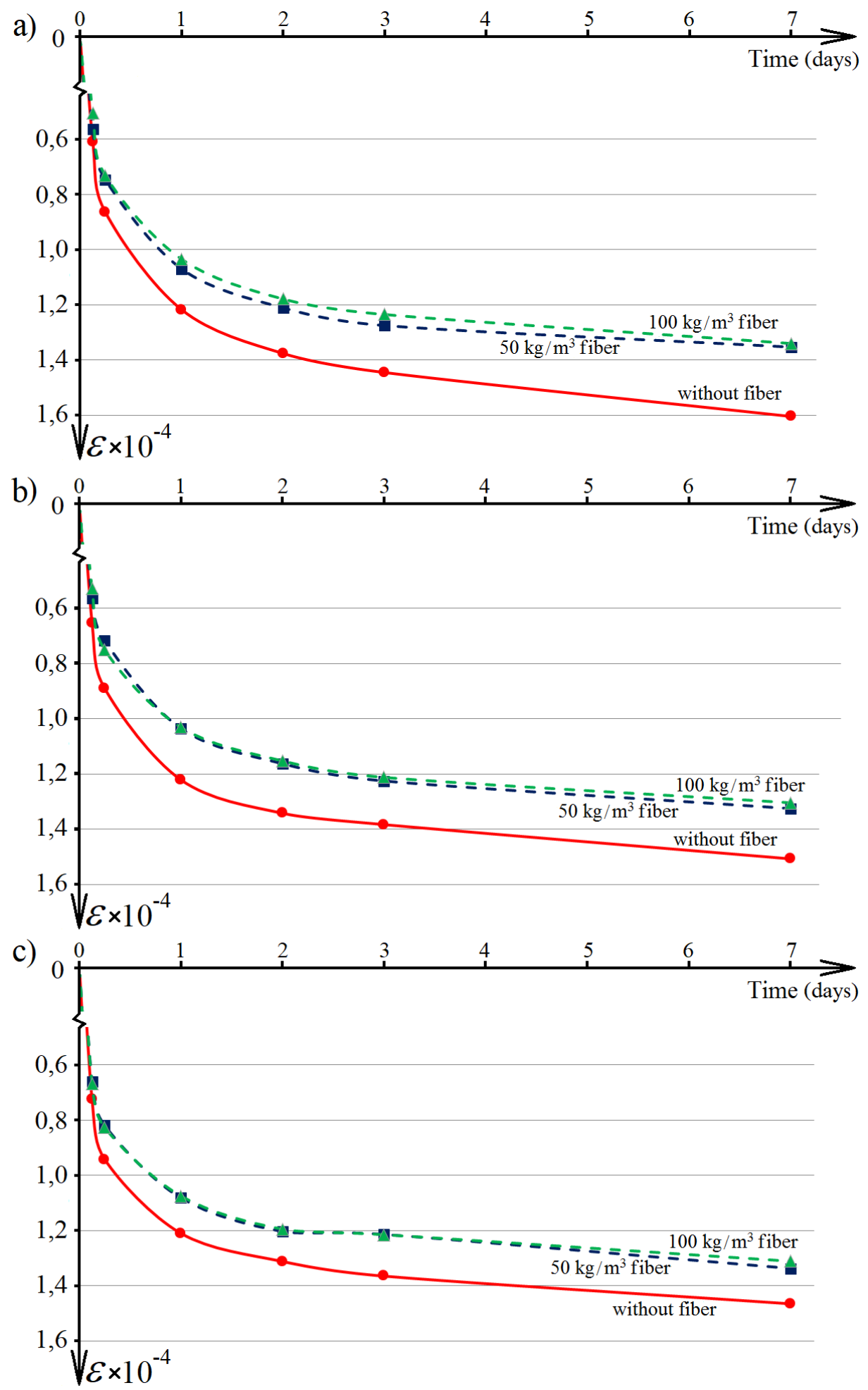

Fig. 1. Shrinkage of concrete and fiber-reinforced concrete at hardness in air-dry conditions:
a) concrete without hardening accelerator (№1, №4, №7);
b) 1,2\% hardening accelerator Sika Rapid 3 (№2, №5, №8);
c) 2,4\% hardening accelerator Sika Rapid 3 (№3, №6, №9)

To determine the general influence of the varied composition factors on the shrinkage of the investigated concretes according to the data given in Table 2, an experimental-statistical (ES) model was built [11] of the change in the shrinkage value at the 7 days age $\varepsilon_{7}$ : 


$$
\begin{gathered}
\varepsilon_{7} \times 10^{-4}=1,323-0,031 \mathrm{x}_{1}+0,023 \mathrm{x}_{1}{ }^{2}+0,027 \mathrm{x}_{1} \mathrm{x}_{2} \\
-0,104 \mathrm{x}_{2}+0,083 \mathrm{x}_{2}{ }^{2}
\end{gathered}
$$

According to the ES-model, a diagram was built (Fig. 2). Shrinkage at the 7 days age is not limiting, but the general nature of the influence of factors on the value of $\varepsilon_{7}$ and limiting shrinkage is similar. According to the analysis of the influence of variable factors on $\varepsilon_{7}$, it is possible to draw conclusions regarding their effectiveness in reducing the shrinkage of the material for the repair rigid road and airfield pavements in general. As shown in Fig. 2 diagram, with the amount of steel fiber from 60 to $90 \mathrm{~kg} / \mathrm{m}^{3}$ and the amount of the hardening accelerator from 1,0 to 2,1\%, the shrinkage of the investigated concretes $\varepsilon_{7}$ is minimal, not higher than $1,3 \times 10^{-4}$. Thus, proceeding from the minimization of volumetric changes in the material during hardening, it can be predicted that fiberconcrete compositions with a rational amount of dispersed reinforcement and an accelerator will be characterized by better adhesion to the base, which is important for repair materials.

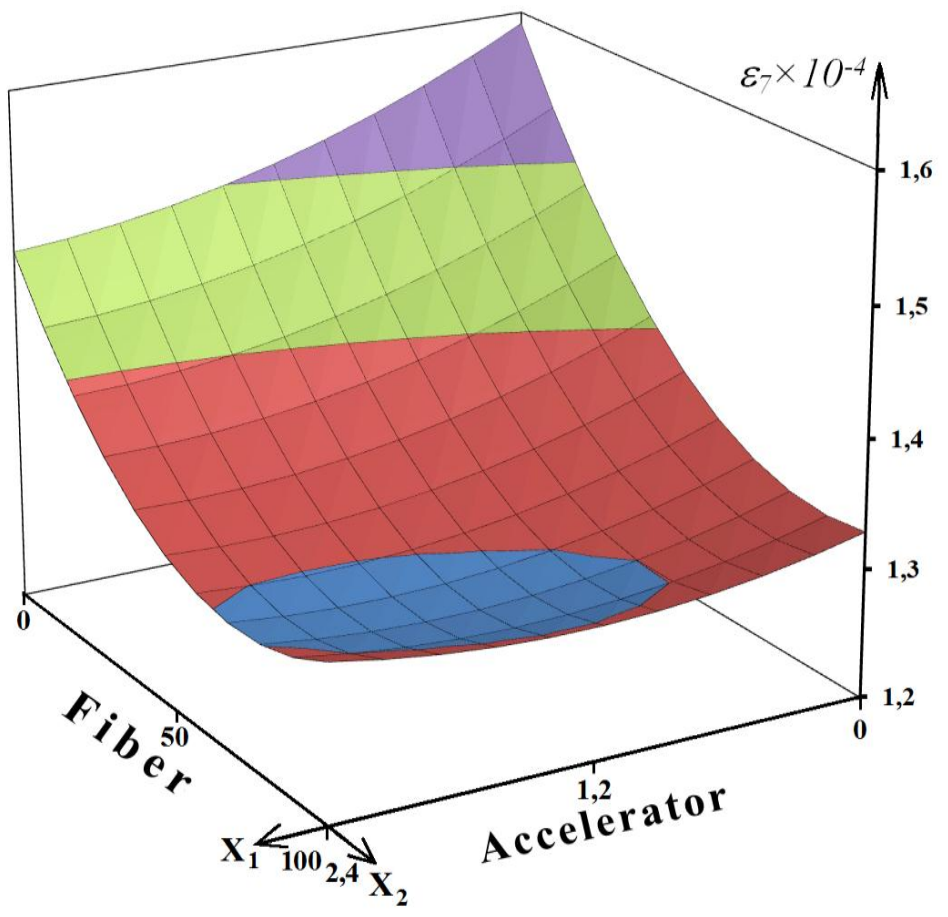

Fig. 2. Influence of variable composition factors on shrinkage of concrete and fiber-reinforced concrete after 7 days of concrete hardening in air-dry conditions

Conclusions and prospects for further research. Due to the use of a rational amount of anchor steel fiber $\left(60 \ldots 90 \mathrm{~kg} / \mathrm{m}^{3}\right)$ and a hardening accelerator $(1,0 . .2,1 \%$ of the cement content), the concrete shrinkage for the rigid pavements repair is reduced by $18 . .20 \%$. After 7 days of hardening in air-dry conditions, the shrinkage of fiber-reinforced concrete with an accelerator is $1,29 \times 10^{-4}$, and of concrete without fiber and an accelerator $-1,60 \times 10^{-4}$. In this case, the ultimate concrete shrinkage is no more than $\varepsilon \approx 2,5 \times 10^{-4}$, or $0,25 \mathrm{~mm} / \mathrm{m}$. Minimization of volumetric changes during hardening allows predicting high resistance of concrete against cracking and will provide better adhesion to the base, which is important for repair materials.

In further studies, it is envisaged to determine the adhesion of the developed concretes and fiberreinforced concretes to the concrete road and airfield pavements, to develop effective technological methods for carrying out full-depth rapid repair using modified fiber-reinforced concrete. 


\section{References}

[1] Official Site of the Federal Highway Administration, Full-Depth Repairs [Online]. Available: https://www.fhwa.dot.gov/pavement/concrete/full.cfm

[2] H. Soliman, J. Lambert, A. Shalaby, T. Liske, S. Kass, L. Deane, "Characterizing field and laboratory performance of cementitious partial depth repair materials", Conference and Exhibition of the Transportation Association of Canada - Transportation Successes: Let's Build on Them, TAC/ATC 2011, Edmonton, AB, 103251, 2011.

[3] N. Shanahan, D. Buidens, K. Riding, A. Zayed, C. Jantzen, "Effect of chloride-based accelerator in the presence of water-reducing and retarding admixture on autogenous shrinkage", Journal of the American Ceramic Society, 99(6), pp. 2147-2158, 2016, doi:10.1111/jace.14221.

[4] A.V. Klyuyev, A.V. Durachenko, "Fibrobetony dlya remonta dorozhnykh pokrytiy na osnove steklyannoy fibry", Mezhdunarodnyy zhurnal prikladnykh $i$ fundamental'nykh issledovaniy, no. 1, pp. 207-210, 2017.

[5] M. Darter, Concrete repair best practices: a series of case studies, Report № cmr-17-013, 2017.

[6] S.Y. Choi, J.S. Park, W.T. Jung, "A study on the shrinkage control of fiber reinforced concrete pavement", Procedia Engineering, 14, pp. 2815-2822, 2011. doi:10.1016/j.proeng.2011.07.354.

[7] Y. Mohammadi, H.M. Ghasemzadeh, T.B. Talari, M.A. Ghorbani, "Replacing fibre reinforced concrete with bitumen asphalt in airports", International journal of civil and environmental engineering, vol. 3, no. 10, pp. 351-355, 2009.

[8] N. Kabashi, C. Krasniqi, R. Hadri, A. Sadikah, "Effect of fibre reinforced concrete and behavior in rigid pavements", International journal of structural and civil engineering research, vol. 7, no. 1, pp. 29-33, 2018. doi: 10.18178/ijscer.7.1.29-33.

[9] S. Kroviakov, V. Kryzhanovskyi, M. Zavoloka, "Steel fibrous concrete with high-early strength for rigid pavements repair", IOP Conf. Series: Materials Science and Engineering, 1162, no. 012008, 2021. doi: 10.1088/1757-899X/1162/1/012008.

[10] V.O. Kryzhanovskiy, S.O. Kroviakov, "Strength of rigid pavement concretes modified with polycarboxylate admixture on different types of cement", Visnyk Odes'koyi derzhavnoyi akademiyi budivnytstva ta arkhitektury, no. 79, pp. 92-98, 2020. doi: 10.31650/2415-377X-2020-79-92-98.

[11] T.V. Lyashenko, V.A. Voznesensky, Metodologiya retsepturno-tekhnologicheskikh poley v komp'yuternom stroitel'nom materialovedenii, Odessa: Astroprint, 2017.

[12] C.F. Jeff Wu, M.S. Hamada, Experiments: Planning, Analysis, and Optimization. $2 d$ ed, Wiley \& Sons, 2009.

[13] L.Y. Dvorkin, A.V. Mishutin, S.O. Krovyakov, O.M. Bordyuzhenko, L. Chintea, Efektyvni vydy fibrobetoniv, Odesa: ODABA, 2021.

[14] V. Afroughsabet, L. Biolzi, T. Ozbakkaloglu, "High-performance fiber-reinforced concrete: a review", Journal of Materials Science, 51 (14), pp. 6517-6551, 2016. 


\title{
ВПЛИВ ДИСПЕРСНОГО АРМУВАННЯ НА УСАДКУ БЕТОНУ ДЛЯ РЕМОНТУ ЖОРСТКИЙ ДОРОЖНІХ І АЕРОДРОМНИХ ПОКРИТТІВ
}

\author{
${ }^{1}$ Кровяков С.О., д.т.н., доцент, \\ skrovyakov@ukr.net, ORCID: 0000-0002-0800-0123 \\ ${ }^{1}$ Крижановський В.О., інженер \\ vitolloscience@gmail.com, ORCID: 0000-0003-1332-1922 \\ ${ }^{1}$ Одеська державна академія будівництва та архітектури \\ вул. Дідріхсона, 4, м. Одеса, 65029, Україна
}

\begin{abstract}
Анотація. Визначено вплив дисперсного армування металевою анкерною фіброю на усадку модифікованих бетонів для ремонту жорстких дорожніх і аеродромних покриттів. Проведено 2-х факторний експеримент, в якому варіювалися наступні фактори складу: кількість добавки прискорювача твердіння Sika Rapid 3, від 0 до 2,4 \% від маси цементу $\left(0 . .9,6\right.$ кг $\left./ \mathrm{M}^{3}\right)$; кількість металевої анкерної фібри діаметром 1 мм і довжиною 50 мм, від 0 до $100 \mathrm{\kappa г} / \mathrm{m}^{3}$. Для виготовлення бетонів використовувалися: портландцемент ПЦ II/А-Ш-500 (CEM II/A-S 42,5) у кількості 400 кг/м³ , гранітний щебінь фракції 5-20 мм, кварцовий пісок, пластифікуюча добавка BASF MasterGlenium SKY 608 у кількості 1,2\% від маси цементу.

Рухомість сумішей була S2, відповідно їх В/Ц залежало від складу. За рахунок використання суперпластифікатору В/Ц всіх досліджених сумішей знаходилося в межах $0,309 . .0,343$.
\end{abstract}

Усадка зразків-призм фіксувалася після 3 годин, 6 годин, 1, 2, 3 і 7 діб знаходження у повітряно-сухих умовах. Процес усадки не завершується після 7 діб твердіння бетону, проте загальний характер впливу варійованих факторів на його величину зберігається. Встановлено

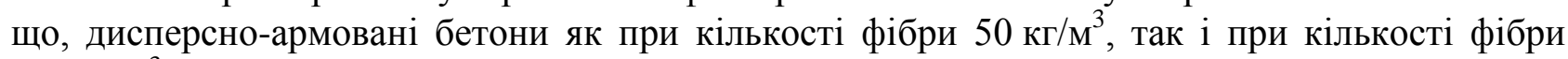
100 кг/м м $^{3}$ мають на $10 . .15 \%$ меншу усадкою в порівнянні з неармованими. Склади з кількістю

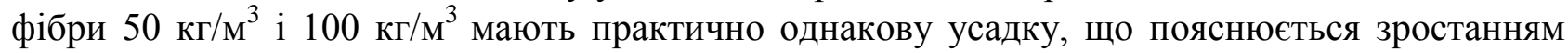
В/Ц при підвищенні кількості дисперсної арматури. Кількість прискорювача твердіння менш відчутно впливає на величину усадки бетонів. За рахунок введення Sika Rapid 3 усадка бетону у віці 7 діб знижується на 2..9\%. Цей ефект можна пояснити тим, що внутрішні напруження, які виникають в процесі структуроутворення та втрати вологи бетоном, стримуються більш міцною цементно-піщаною матрицею. Усадка бетону без фібри i прискорювача також вимірювалася у віці до 98 діб. Встановлено, що гранична усадка для такого бетону складає $\varepsilon \approx 2,5 \times 10^{-4}$.

Аналіз побудованої експериментально-статистичної моделі показав, що при кількості металевої фібри від 60 до 90 кг/м м $^{3}$ кількості прискорювача твердіння від 0,9 до 2,4\% усадка досліджених бетонів $є$ мінімальною $\left(\varepsilon_{7}=1,3 \times 10^{-4}\right)$.

Таким чином, використання дисперсного армування анкерною металевою фіброю i прискорювача твердіння дозволяє суттєво знизити усадку бетону для ремонту жорстких дорожніх і аеродромних покриттів, що важливо для даного матеріалу.

Ключові слова: жорсткі дорожні покриття, аеродромні покриття, ремонт, усадка, металева фібра, прискорювач твердіння. 


\title{
ВЛИЯНИЕ ДИСПЕРСНОГО АРМИРОВАНИЯ НА УСАДКУ БЕТОНА ДЛЯ РЕМОНТА ЖЕСТКИХ ДОРОЖНЫХ И АЭРОДРОМНЫХ ПОКРЫТИЙ
}

\author{
${ }^{1}$ Кровяков С.А., Д.Т.Н., доцент, \\ skrovyakov@ukr.net, ORCID: 0000-0002-0800-0123 \\ ${ }^{1}$ Крыжановский В.А., инженер, \\ vitolloscience@gmail.com, ORCID: 0000-0003-1332-1922 \\ ${ }_{1}^{1}$ Одесская государственная академия строительства и архитектуры \\ ул. Дидрихсона, 4, г. Одесса, 65029, Украина
}

\begin{abstract}
Аннотация. Определено влияние дисперсного армирования металлической анкерной фиброй на усадку модифицированных бетонов для ремонта жестких дорожных и аэродромных покрытий. Проведен 2-х факторный эксперимент, в котором варьировались следующие факторы состава: количество добавки ускорителя твердения Sika Rapid 3, от 0 до 2,4\% от массы цемента $\left(0 . .9,6\right.$ кг $\left./ \mathrm{M}^{3}\right)$; количество металлической анкерной фибры диаметром 1 мм и длиной 50 мм, от 0 до 100 кг $\mathrm{M}^{3}$. Для изготовления бетонов использовались: портландцемент ПЦ II/А-Ш-500 (СЕМ

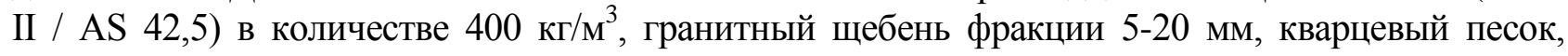
пластифицирующая добавка BASF MasterGlenium SKY 608 в количестве 1,2\% от массы цемента.

Подвижность смесей составляла $\mathrm{S} 2$, соответственно их В/Ц зависело от состава. За счет использования суперпластификатора В/Ц всех исследованных смесей находилось в пределах 0,309..0,343.
\end{abstract}

Усадка образцов-призм фиксировалась после 3 часов, 6 часов, 1, 2, 3 и 7 суток нахождения в воздушно-сухих условиях. Процесс усадки не заканчивается после 7 суток твердения бетона, однако общий характер влияния варьируемых факторов на его величину сохраняется. Установлено, что, дисперсно-армированные бетоны как при количестве фибры 50 кг/м³ , так и при количестве фибры $100 \mathrm{\kappa} / \mathrm{M}^{3}$ имеют на 10..15\% меньшую усадку по сравнению с

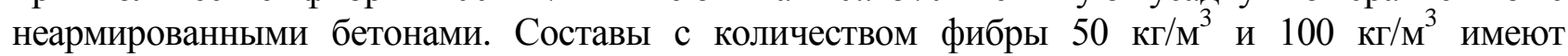
практически одинаковую усадку, что объясняется ростом В/Ц при повышении количества дисперсной арматуры. Количество ускорителя твердения менее ощутимо влияет на величину усадки бетонов. За счет введения Sika Rapid 3 усадка бетона в возрасте 7 суток снижается на $2 . .9 \%$. Этот эффект можно объяснить тем, что внутренние напряжения, возникающие в процессе структурообразования и потери влаги бетоном, сдерживаются более прочной цементнопесчаной матрицей. Усадка бетона без фибры и ускорителя также определялась в возрасте до 98 суток. Установлено, что предельная усадка для такого бетона составляет $\varepsilon \approx 2,5 \times 10^{-4}$.

Анализ построенной экспериментально-статистической модели показал, что при количестве металлической фибры от 60 до 90 кг/м ${ }^{3}$ и количества ускорителя твердения от 0,9 до 2,4\% усадка исследованных бетонов является минимальной $\left(\varepsilon_{7}=1,3 \times 10^{-4}\right)$.

Таким образом, использование дисперсного армирования анкерной металлической фиброй и ускорителя твердения позволяет существенно снизить усадку бетона для ремонта жестких аэродромных покрытий, что важно для данного материала.

Ключевые слова: жесткие дорожные покрытия, аэродромные покрытия, ремонт, усадка, металлическая фибра, ускоритель твердения.

Стаття надійшла до редакції 30.08.2021 